\title{
Characterization of particleboards produced with Pinus spp. waste
}

\author{
Caracterização de painéis de partículas produzidos \\ com resíduos de madeira de Pinus spp.
}

\author{
João Vítor Felippe Silva1, Bruno Santos Ferreira², Cristiane Inácio de Campos ${ }^{3}$, \\ André Luis Christoforo ${ }^{4}$ e Francisco Antonio Rocco Lahr ${ }^{5}$
}

\begin{abstract}
Resumo
A utilização de resíduos é fundamental para a minoração dos impactos ambientais, consistindo as madeireiras nas principais fontes de geração de resíduos deste material, provenientes do procesamento da madeira. Painéis à base de madeira consistem em uma possibilidade de aplicação desses resíduos, e estudos recentes têm sido desenvolvidos visando a obtenção de melhor qualidade desses produtos. Esta pesquisa teve como objetivo produzir e avaliar painéis de partículas de média densidade (MDF) fabricados com resíduos de madeira de Pinus spp. com dimensões de partículas variadas e resina ureia-formaldeído como adesivo. As propriedades físicas e mecânicas investigadas, bem como os requisitos foram obtidos de acordo com a norma brasileira ABNT (2006). As propriedades físicas investigadas foram a densidade, teor de humidade e o inchamento em espessura e absorção de água após duas horas de imersão em água, e as propriedades mecânicas foram a resistência na tração perpendicular, módulo de elasticidade (MOE) e o módulo de ruptura (MOR). Três tratamentos foram delineados de acordo com o tipo de resíduo, no primeiro tratamento, os painéis foram produzidas com resíduos de folhas de madeira, no segundo tratamento foram utilizados resíduos provenientes do processamento da madeira, e o terceiro consistiu na composição de ambos. O primeiro tratamento apresentou ser o de menor variação nas propriedaes avaliadas (material mais homogêneo), e com relação as melhores propriedades físicas e mecânicas, estas foram provenienets do terceiro tratamento, que proporcionaram paineis de maior densidade, menor absorção de água e valores mais elevados para a resistência na tração perpendicular, MOE e MOR.
\end{abstract}

Palavras-chave: painéis de média densidade, resídos de madeira, uréia formaldeído.

\begin{abstract}
The use of waste is essential to minimize environmental impacts; in the case of logging companies, these are in the main source of waste generation from timber processing. Wood based panels are a possibility of using these wastes and recent studies have been developed to obtain the best quality of those products. This research aimed to produce and evaluate medium density particleboard (MDP) manufactured with Pinus spp. wood residues (wood veneers and processed wood) and urea formaldehyde resin as adhesive. The physical and mechanical properties of the panels, as well as quality requirements were obtained according to the Brazilian standard ABNT (2006). The physical properties studied were density, moisture content, thickness swelling and water absorption after two hours, and the mechanical properties evaluated were internal bonding, modulus of elasticity (MOE) and modulus of rupture (MOR). Three treatments according to the source of the material were used; in the first treatment, the panels were produced with wood veneers residues, in the second treatment large dimensional residues from sawmill (processed wood) were used; and in the third treatment both residues were used. The first treatment presented low variation in the results (more homogeneous material), while the last treatment yielded the best results, with a higher density, low absorption of water and higher values for internal bonding, MOE and MOR.
\end{abstract}

Keywords: medium density particleboard, wood residues, urea formaldehyde.

\footnotetext{
${ }^{1}$ Graduando em Engenharia Industrial Madeireira. UNESP - Universidade Estadual Paulista "Júlio de Mesquita Filho" - Campus Itapeva. Rua Geraldo Alckmin, 519 - Vila Nossa Senhora de Fátima, Itapeva - SP, 18409-010. E-mail: joao.vitor@grad.itapeva.unesp.br.

2Doutorando do Programa de Pós-Graduação em Engenharia Mecânica. UNESP - Universidade Estadual Paulista "Julio de Mesquita Filho / FEG - Faculdade de Engenharia de Guaratinguetá. Av. Ariberto Pereira da Cunha, 333 - 12.516 -10 Guaratinguetá, SP, Brasil. E-mail: brunosferreira@gmail.com;

3Professora Assistente Doutora. UNESP - Universidade Estadual Paulista "Júlio de Mesquita Filho" - Campus Itapeva. Rua Geraldo Alckmin, 519 - Vila Nossa Senhora de Fátima, Itapeva - SP, 18409-010. E-mail: cristiane@itapeva.unesp.br.

${ }^{4}$ Professor Adjunto do Departamento de Engenharia Civil. UFSCar - Universidade Federal de São Carlos. Rodovia Washington Luís, km 235 - SP-310 -36307352 - São Carlos, SP, Brasil. E-mail: christoforoal@yahoo.com.br.

${ }^{5}$ Professor Titular do Departamento de Engenharia de Estruturas. USP - Universidade de São Paulo / EESC - Escola de Engenharia de São Carlos. Av. Trabalhador Sãocarlense, 400 - 13566590 - São Carlos, SP, Brasil. E-mail: frocco@sc.sup.br.
}

Sci. For., Piracicaba, v. 44, n. 111, p. 623-628, set. 2016 DOI: dx.doi.org/10.18671/scifor.v44n111.08 


\section{INTRODUCTION}

Brazil has a large area of forests, however, over the years, the idea of sustainability has emerged and forest exploitation needed to be reduced. Due this fact, new technologies were designed to minimize the generation of wood wastes from forest harvesting for timber production to the production of furniture and structures. Even with these new technologies rising, most processes with wood are made with old technology for economic reasons, and thus generating large amounts of wood residues in the factories. Mechanical processing of wood generates at last $40 \%$ of residues from the volume of the log in the form of wood chips, bark, sawdust, wood shavings, and more.

Wood industry wastes are defined as the remains of mechanical, physical or chemical processing that are not incorporated into the final product (PIERRE, 2010). Most of these residues come without any chemical treatment, resulting from the processing of logs and wood pieces or from products at the end of their useful life that are discarded as waste to be burned (TEIXEIRA, 2005). For over a decade research has demonstrated the viability of the use of residues and emphasized the need for better use of raw materials and rational use of forest resources (IWAKIRI, 2005).

Forest wastes can be used in many ways as manufacture of SWO (small wooden objects), as biomass, in packing filling, in paint industry and in the production of particleboards (BARBOSA, 2008).

The production of wood-based panels is a good alternative of application of those wood wastes; the main types of panels are plywood, particleboards and fiberboards. The great growth of panel industries in Brazil is something remarkable in the world market, making it one of the most important segments in the forestry context; this was only possible because of the excellent conditions for the growth of forest plantation and large areas for this purpose (MENDES et al., 2000). In Brazil, the raw material used by panel industries comes mostly from planted forests, with species of Pinus and Eucalyptus being the majority (MELO, 2009).

Particleboard is a wood-based panel with thickness ranging from $3 \mathrm{~mm}$ to $50 \mathrm{~mm}$, consisting of wood particles bonded with natural or synthetic thermoset resin consolidated under action of pressure and heat (ABNT, 2013a).

Medium Density Particleboard (MDP) is an improvement of the particleboard due its production process and final product quality. The particles are positioned in three layers, the largest ones are used in the core layer of the panel and the smallest ones are used at the external layers, giving a better quality to the surface (MACIEL, 2001).

The main objective of this research consists in characterizing particleboards produced with wood wastes from wood veneers and large wooden residues from sawmill, and compare the results with the Brazilian standards (ABNT, 2006, 2013a, 2013b) and other research in the area.

\section{MATERIAL AND METHODS}

The materials used in the production of the MDP were Pinus spp. wastes, urea formaldehyde adhesive, paraffin emulsion and ammonium sulfate. The wood residues were defective wood veneers and large dimensional wood wastes from sawmill; those materials were donated by the Laboratory of Material Properties and Wood Processing from UNESP, campus of Itapeva.

For the production of the adhesive, urea formaldehyde resin with solids content of $65 \%$ and $\mathrm{pH}$ near to 7 was used with ammonium sulfate as a curing catalyst and paraffin emulsion to improve the water resistance.

The nominal dimensions of the particleboards were $450 \mathrm{~mm} \times 450 \mathrm{~mm} \times 15 \mathrm{~mm}$, and it was produced in three layers and three different compositions as shown in Table 1.

Table 1. Panel composition in each treatment.

Tabela 1. Composição dos painéis por tratamento.

\begin{tabular}{llc}
\hline Treatment & Raw Material & $\%$ \\
\hline T1 & Wood veneers & 100 \\
T2 & Large dimensional wood waste & 100 \\
T3 & Wood veneers / Large dimensional wood waste & $50 / 50$ \\
\hline
\end{tabular}


For each treatment two particleboards were produced using $2200 \mathrm{~g}$ of particles, with $440 \mathrm{~g}$ for the external layers composed of 16 and 40 mesh particles and 1320g for the core layer composed of 9 mesh particles. The pressure applied was $40 \mathrm{kgf} / \mathrm{cm}^{2}$ (235 bar), with a temperature of $120^{\circ} \mathrm{C}$ and 10 minutes of pressing time with a pressure relief of 30 seconds after 5 minutes of pressure applied.

Initially, the wood residues were reduced to smaller dimensions through a wood chopper and then they were reduced for a second time with a knife mill of the Wiley type. Thereafter, the material was classified according to its dimension (9, 16 and 40 mesh) using an electromagnetic stirrer coupled to a set of sieves.

The classified particles were then dried for 24 hours at a temperature of $103^{\circ} \mathrm{C} \pm 5^{\circ} \mathrm{C}$ in a forced air laboratory oven, until the particles had the desired moisture content between $3 \%$ and $6 \%$.

The adhesive was prepared according to the dry weight of the particles. It was composed by $10 \%$ of urea formaldehyde, $1 \%$ of paraffin emulsion, $1 \%$ of ammonium sulfate and $1.5 \%$ of water. The four components were mixed with the wood particles using an industrial mixer.

The adhesive impregnation on each panel took place in four stages, two stages for the mixture of the external layers and two stages for the core layer, each portion mixed with the corresponding quantity of adhesive. Thereafter, the impregnated particles were disposed inside a wood form on a steel plate covered with aluminum foil. The particles with the adhesive were spread manually, as uniformly as possible.

Then the wood form was removed and another steel plate covered with aluminum foil was placed over the particle mattress and taken to a hydraulic press with a heating system. Some equipment used in this study is shown in Figure 1.

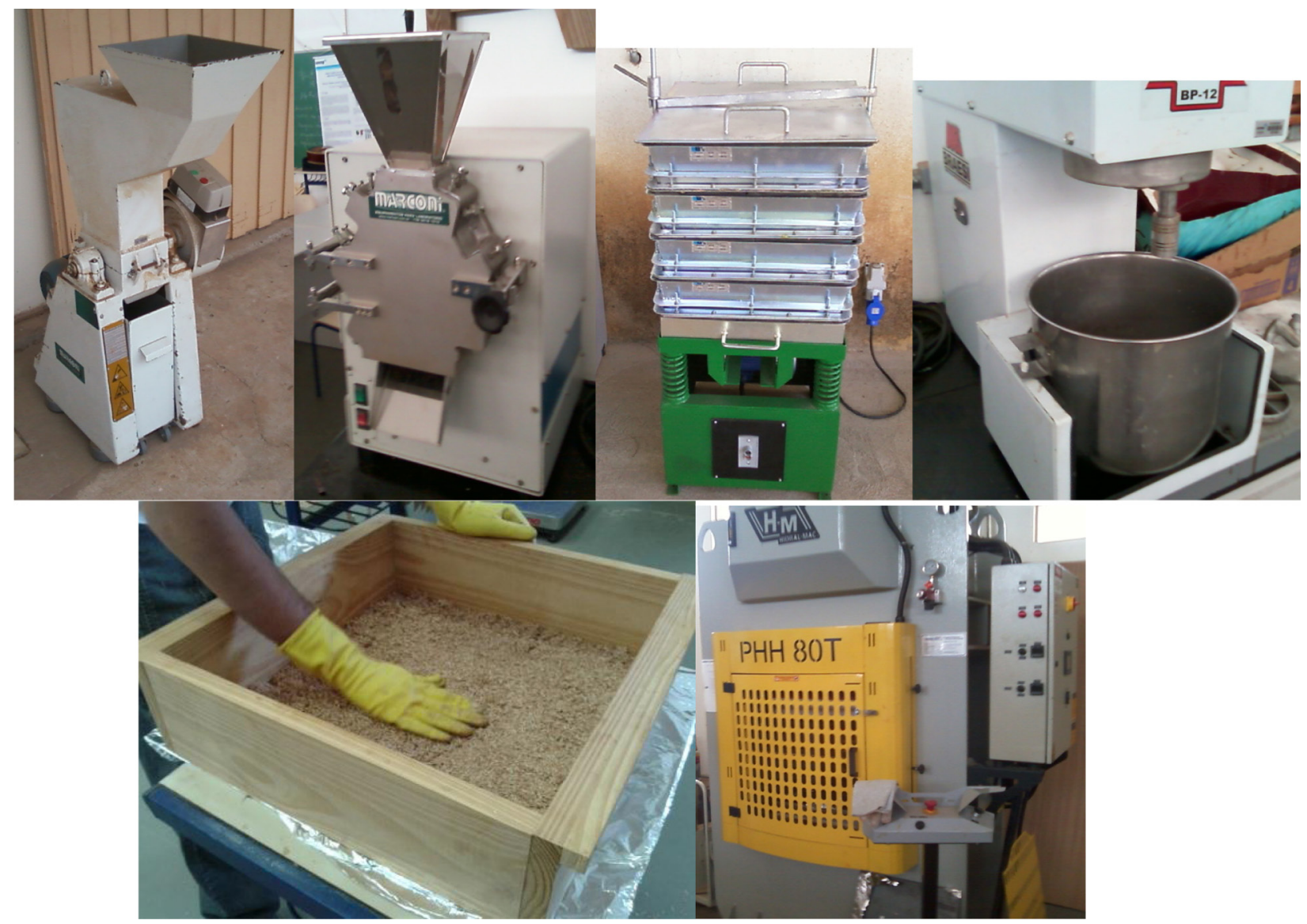

Figure 1. Equipment used for the production of the MDP.

Figura 1. Equipamentos utilizadas na produção dos MDP.

After the pressing cycle, the panels were removed from the press and placed in a room with constant temperature and humidity, according with the normative specifications for at least 72 hours, and then the samples were removed from the panels to perform the tests.

The physical tests performed were the determination of density, moisture content, water absorption (in two hours of immersion) and thickness swelling ( 2 hours). The mechanical tests performed 
were: internal bond, modulus of elasticity (MOE) and modulus of rupture (MOR); all tests according to Brazilian standard ABNT (2006). Some tests are shown in Figure 2.
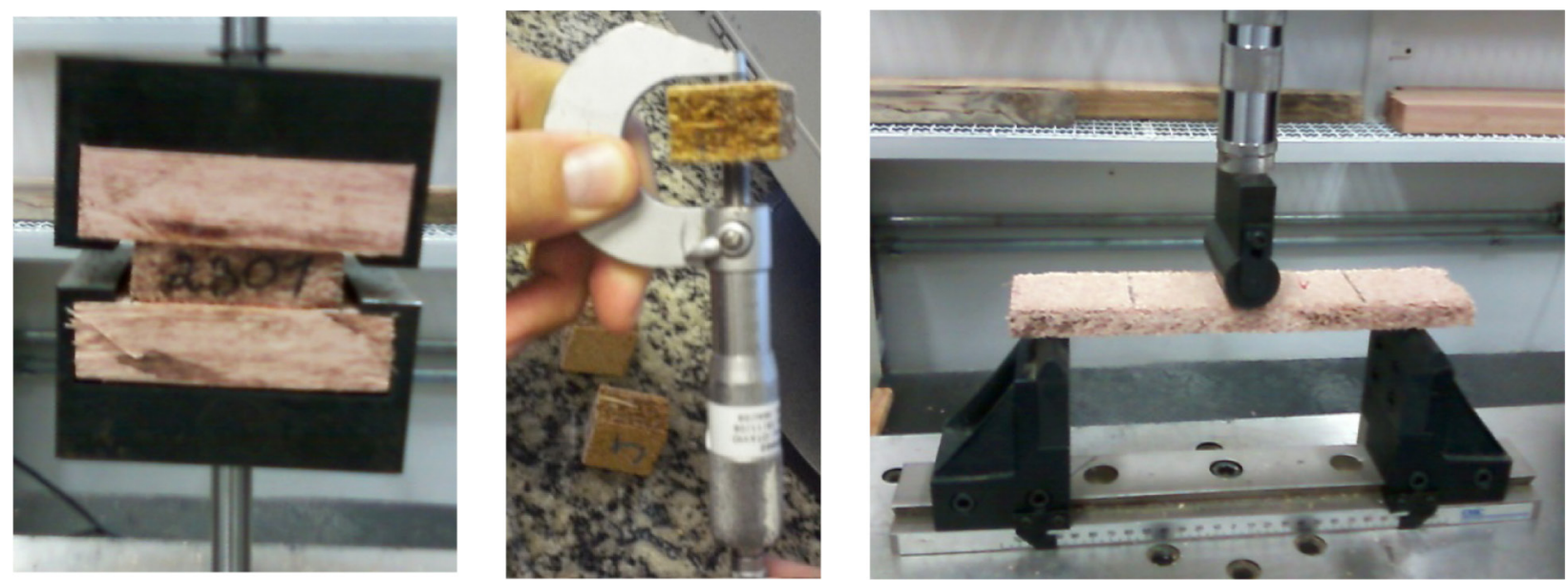

Figure 2. Some tests performed on the MDP.

Figura 2. Alguns ensaios realizados na caracterização dos MDP.

The results of physical and mechanical properties were evaluated through the analysis of variance (ANOVA) and Tukey test with 95\% family-wise confidence level, using the software R version 3.01.

\section{RESULTS AND DISCUSSION}

The mean values for physical and mechanical properties, followed by the analysis of variance results and the standard deviation between brackets are presented in Table 2 .

Table 2. Mean values of physical and mechanical properties investigated.

Tabela 2. Valores médios das Propriedades físicas e mecânicas investigadas.

\begin{tabular}{lccc}
\hline \multirow{2}{*}{ Tests } & \multicolumn{3}{c}{ Treatments } \\
\cline { 2 - 4 } & $750 \mathrm{~b}^{*}(30)$ & T2 & T3 \\
\hline Density $\left[\mathrm{kg} / \mathrm{m}^{3}\right]$ & $9.48 \mathrm{a}(0.26)$ & $5.02 \mathrm{c}(1.69)$ & $930 \mathrm{a}(50)$ \\
Moisture contente [\%] & $10.03 \mathrm{~b}(1.46)$ & $55.36 \mathrm{a}(13.49)$ & $12.51 \mathrm{~b}(1.01)$ \\
Water absorption 2 hours [\%] & $4.03 \mathrm{~b}(0.99)$ & $44.27 \mathrm{a}(12.07)$ & $9.14 \mathrm{~b}(5.66)$ \\
Thickness swelling 2 hours [\%] & $0.27 \mathrm{~b}(0.07)$ & $0.15 \mathrm{~b}(0.07)$ & $0.69 \mathrm{a}(0.26)$ \\
Internal bond [MPa] & $1350 \mathrm{~b}(630)$ & $630 \mathrm{c}(280)$ & $1970 \mathrm{a}(370)$ \\
MOE [MPa] & $6.75 \mathrm{~b}(1.19)$ & $4.60 \mathrm{c}(1.95)$ & $13.69 \mathrm{a}(2.61)$ \\
MOR [MPa]
\end{tabular}

*Same letters on horizontal means no statistical difference among the mean values.

The mean values of density did not differ between treatments $\mathrm{T} 1$ and T2, both being classified as medium density particleboards. The treatment $\mathrm{T} 3$ presented a higher value of density and it was classified as a high-density particleboard. Density was the factor that most influenced the mechanical properties of the particleboard. The increase of density led to an increase in MOE, MOR and internal bond (CAI et al., 2004).

It is emphasized that the type of residue used influenced the results obtained due to the shape and density of the material used to make the panels; thus directly interfering with compression and final density.

The particleboard moisture content is related to the initial moisture content, and as expected treatment T3 presented a mean value of moisture content between treatment T1 and T2. It is also observed that the variability of treatment $\mathrm{T} 1$ is lower than the others, indicating greater material homogeneity.

Note that the wastes were used in their natural conditions; therefore they did not undergo any drying process. Although there is difference between the results presented for the tree treatments, all met the specifications (ABNT, 2013b). 
On water absorption and thickness swelling for 2 hours, the treatment T1 had the lowest mean values and variation of the data, but the mean values did not differ statistically from treatment $\mathrm{T} 3$, this last one had a higher variability. Treatment T2 presented a larger disparity of values than the other treatments; with a higher mean and standard deviation indicating undesirable characteristics of a particleboard.

It is noteworthy that the use of residual pieces of wood influenced the geometry of the waste, which gave the worst performance of these panels when in contact with water. The geometry that has greater thickness provides a reduced slenderness ratio and causes a worse performance of the material in contact with water (HASELEIN et al., 2002).

The internal bond test showed no statistical difference between treatments $\mathrm{T} 1$ and T2, both with mean values lower than those required of $0.35 \mathrm{MPa}$ for particleboards of the type $\mathrm{P} 2$ for internal use in dry conditions (ABNT, 2013b); only treatment T3 achieved compatible values.

Smaller length particles have smaller surface area, resulting in larger amount of voids and a lower adhesion among the other particles (FERREIRA et al., 2014), which was observed particularly in treatment $\mathrm{T} 2$.

On the bending tests to determinate MOE and MOR, the three treatments were statistically different, particleboards from type P2 for internal use in dry conditions with thickness between $13 \mathrm{~mm}$ and $20 \mathrm{~mm}$ must have the MOE value over $1600 \mathrm{MPa}$, and the MOR over $11 \mathrm{MPa}$ (ABNT, 2013b). In both cases, only treatment $\mathrm{T} 3$ achieved the values for commercial application according to the Brazilian standard.

Again, it is worth noting that the best interaction between the particles provided by the geometry affect the performance of the panels in the bending test. As seen in previous studies, the highest density of the panel provided better mechanical performance.

\section{CONCLUSIONS}

It can be concluded that particleboards produced with residues of plywood sheets are more homogeneous in all tests performed, and particleboards produced with large dimensional wood waste achieved less homogeneous values in all tests.

The treatment T3 achieved intermediate values in the physical tests, except in the density test, which affected the mechanical properties with higher values than the other treatments, and showed a possibility of commercial application for internal use under dry conditions.

Treatments T1 and T2 did not reach the standard specifications; however, they can be used in applications with low physical and mechanical demand, as decorative panels, small wooden objects and craft objects. It is also noted that there is the possibility of partial use of residues in the panel composition without compromising its general properties.

\section{ACKNOWLEDGMENTS}

The authors thank the National Council of Scientific and Technological Development (CNPq) for supporting this research.

\section{REFERENCES}

ABNT - ASSOCIAÇÃO BRASILEIRA DE NORMAS TÉCNICAS. NBR 14810-3: Chapas de madeira aglomerada: métodos de ensaio. Rio de Janeiro, 2006.

ABNT - ASSOCIAÇÃO BRASILEIRA DE NORMAS TÉCNICAS. NBR 14810-1: Chapas de madeira aglomerada: terminologia, Rio de Janeiro, 2013a.

ABNT - ASSOCIAÇÃO BRASILEIRA DE NORMAS TÉCNICAS. NBR 14810-2: Chapas de madeira aglomerada: requisitos. Rio de Janeiro, 2013b.

BARBOSA, C. F. Produção de um móvel infantil a partir de resíduo proveniente da indústria moveleira. Itapeva: CEIM/UNESP, 2008. 
Ferreira et al. - Caracterização de painéis de partículas produzidos com resíduos de madeira de Pinus spp.

CAI, Z.; WU, Q.; LEE, J. N.; HIZIROGLU, S. Influence of board density, mat construction, and chip type on performance of particleboard made from eastern red cedar. Forest Products Journal, Madson, v. 54, n. 14, p. 226-232, dez. 2004.

FERREIRA, B. S.; CAMPOS, C. I.; GONÇALVES, M. T. T. Use of Macadamia Nutshell in the Production of Eucalyptus Salign Particleboards. Advanced Materials Research, Switzerland, v. 1025-1026, p. 246-250, set. 2014.

HASELEIN, C. R.; CALEGARI, L.; BARROS, M. V.; HACK, C.; HILliG, E.; PAULESKI, D. T.; POZZERA, F. Resistência mecânica e à umidade de painéis aglomerados com partículas de madeira de diferentes dimensões. Ciência Florestal, Santa Maria, v. 12, n. 2, p. 127-134, jul. 2002.

IWAKIRI, S. Painéis de madeira reconstituída. Curitiba: FUPEF, 2005. 247 p.

MACIEL, A. S. Chapas de partículas aglomeradas de madeira de Pinus elliottii ou Eucalyptus grandis em mistura com poliestireno e poliestireno tereftalato. 2001. 121 p. Tese (Doutorado em Ciência Florestal) Universidade Federal de Viçosa, Viçosa, 2001.

MELO, R. R. Propriedades físico-mecânicas e resistência a biodeterioradores das chapas aglomeradas constituídas por diferentes proporções de madeira e casca de arroz. 2009. 77 p. Dissertação (Mestrado em Engenharia Florestal) - Universidade Federal de Santa Maria, Santa Maria, 2009.

MENDES, L. M., ALBUQUERQUE, C. E. C., IWAKIRI, S. Perspectivas do processo de produção de painéis OSB. São Carlos: IBRAMEM, 2000.

PIERRE, F. C. Caracterização físico-mecânica de painéis aglomerados de Eucalyptus grandis com adição de resíduos industriais madeireiros. 2010. 122 p. Tese (Doutorado em Ciência Florestal) - Universidade Estadual Paulista "Júlio de Mesquita Filho", Botucatu, 2010.

TEIXEIRA, M. G. Aplicação de conceitos da ecologia industrial para a produção de materiais ecológicos: o exemplo dos resíduos de madeira. 2005. 132 p. Dissertação (Mestrado em Gerenciamento e Tecnologia Ambiental no Processo Produtivo) - Universidade Federal da Bahia, Salvador, 2005.

Recebido em 09/10/2015

Aceito para publicação em 27/01/2016 